\title{
Mechanical characterization of a polyester matrix composite reinforced with natural fibers from Luffa cylindrica Hoen
}

\author{
Edgley Alves de Oliveira PAULAㄹ, Rafael Bezerra Azevedo MENDES², \\ Claudia Yanara Meira da COSTA ${ }^{1}$, Rafael Rodolfo de $\mathrm{MELO}^{3}$, Alexandre Santos PIMENTA ${ }^{4}$, \\ Ramona Rodrigues Amaro de OLIVEIRA ${ }^{3}$, Joana Alice Galdino de SOUZA ${ }^{3}$
}

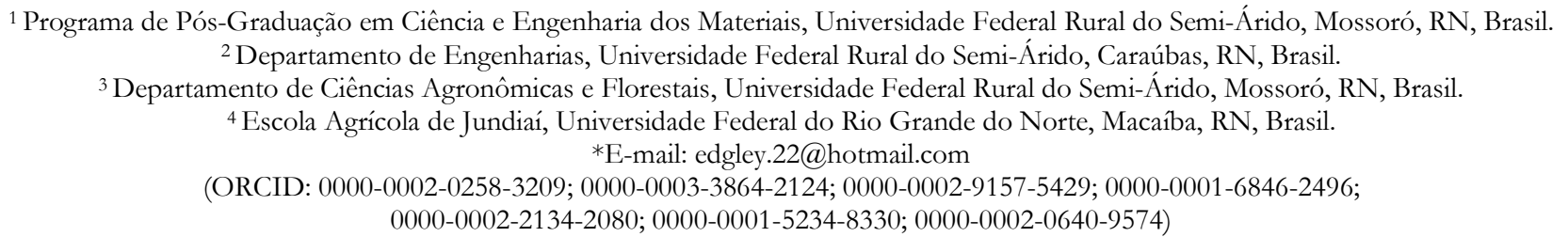

Recebido em 09/08/2021; Aceito em 13/12/2021; Publicado em 17/12/2021.

\begin{abstract}
The growing demand for renewable products has led to many studies of alternative materials. The present work describes the production of a composite based in polyester resin reinforced with fibers from the climber plant Luffa cylindrica and evaluates its mechanical performance. The composite was produced with two perpendicularly-crossed layers of vegetable fibers. The lamination was performed in a mold with two glass plates pressed by a hydraulic press. To characterize the properties of the produced composite, density, tensile and bending strength tests were performed. The final composite had a mean density of $1.16 \mathrm{~g} \mathrm{~cm}^{-3}$, making it light due to the reinforcement with vegetable fibers. Tensile and bending strengths were 13.91 and $26.70 \mathrm{MPa}$, respectively. The experimental results showed that the composite with vegetable fibers as reinforcement had lower density than the pure polyester matrix and composites produced with glass fibers. The tensile strength was higher than the polyester matrix itself, although it was still low. Also, when submitted to bending stress, the composite presented lower resistance than the matrix. Overall, the composite can be a viable alternative for non-structural applications where light materials are required such as handicrafts and office partition.
\end{abstract}

Keywords: sustainable material; vegetable fibers; mechanical properties; technical feasibility.

\section{Caracterização mecânica de um compósito com matriz de poliéster reforçado com fibras naturais de bucha vegetal (Luffa cylindrica Hoen)}

\begin{abstract}
RESUMO: A crescente demanda por produtos renováveis tem levado a muitos estudos de materiais compósitos reforçado com fibras vegetais. A planta trepadeira Luffa cylindrica, conhecida popularmente como bucha vegetal, também apresenta potencial para este uso. O presente trabalho avalia o desempenho de um compósito à base de resina de Poliéster reforçado com bucha vegetal. O compósito foi produzido com duas camadas de fibras vegetais dispostas perpendicularmente entre si. A laminação foi realizada em um molde com duas placas de vidro prensadas por uma prensa hidráulica. Como propriedade física foi determinada a densidade e para as propriedades mecânicas, foram realizados ensaios de resistência à tração e flexão. O compósito final apresentou densidade média de $1,16 \mathrm{~g} \mathrm{~cm}^{-3}$, tornando-o leve devido ao reforço com fibras vegetais. As resistências à tração e flexão foram de 13,91 e $26,70 \mathrm{MPa}$, respectivamente. Os resultados experimentais mostraram que o compósito com fibras vegetais como reforço apresentou densidade menor que a matriz de poliéster pura e compósitos produzidos com fibras de vidro. A resistência à tração foi maior do que a própria matriz de poliéster. Além disso, quando submetido a tensões de flexão, o compósito apresentou menor resistência do que a matriz. No geral, o composto pode ser uma alternativa viável para aplicações não estruturais onde materiais leves são necessários, como artesanatos e paredes divisórias.

Keywords: material sustentável; fibras vegetais; propriedades mecânicas; viabilidade técnica.
\end{abstract}

\section{INTRODUCTION}

The replacement of unsustainable synthetic raw materials with natural ones has been a challenge in many industrial sectors, including the manufacture of composites, where the search new types of polymeric matrices and reinforcements stands out. Among the reinforcements targeted for replacement is fiberglass, which could be substituted successfully by natural fibers without affecting the strength of the composite (SANJAY et al., 2015; WAHIT et al., 2012).
This could be a sustainable alternative for a wide variety of applications, ranging from packaging to the manufacture of automotive parts. The process of producing composites with natural fiber reinforcements has found wide application to make packaging materials (SARIKAYA et al., 2019).

According to Srinivas et al. (2017), polymeric composites consist of the union of a thermoplastic or thermosetting polymer reinforced with fibers. There are three types of polymeric matrix composites: particle-reinforced, fiber- 
reinforced, and structural composites (SRINIVAS et al., 2017). Studies of polymeric composites reinforced with vegetable fibers have been growing rapidly. The use of natural fibers as reinforcement makes composites totally or partially recyclable or biodegradable, in addition to being inexpensive. Among the varieties of lignocellulosic fibers applied as reinforcements in composites are linen, cotton, hemp, jute, sisal, kenaf, pineapple, ramie, bamboo, and banana, among others (ELANCHENZHIAN et al., 2018).

A particularly attractive natural fiber used as reinforcement in composite materials is that of Luffa cylindrica. This plant is an herbaceous species of the Cucurbitaceae family. It is of Asian origin, and arrived in Brazil through Africans. In the Northeast region of Brazil, this plant can be found thriving spontaneously in backyards, riverbanks, and fence borders, where it grows as an annual creeper or perennial climber, reaching up to 5 meters in height. (MEDEIROS, 2015; MOTA, 2016).

The fibers of Luffa cylindrica enable the production of ecological materials that do not harm the environment (MARTINEZ-PAVETTI et al., 2021). Luffa fiber-based composite materials, in addition to being environmentally safe, also provide protection from exposure to various types of toxic chemicals. The fibers are biodegradable and of high porosity, forming naturally strong entangled structure, resulting in high water absorption capacity (BABU; ARUMUGAN, 2019). The fibers are widely used in the manufacture of shoes, rugs, sponges, and mops, and also for the manufacture of value-added products, such as films and fibers for composites. Due to their lightness in weight and low cost, Luffa fibers also have uses in the manufacture of materials for the automotive industry, civil construction and medical applications, among many others (BABU; ARUMUGAN, 2019). However, in Brazil, excepting the eventual use of them as cleaning sponge, there is no largescale or industrial utilization for this natural product.

This article reports the development of a composite with a matrix of polyester resin and reinforcement of Luffa cylindrica fibers and evaluate the physical and mechanical properties of the product.

\section{MATERIAL AND METHODS}

Mats of fibers from Luffa cylindrica fruits (Figure 1A) were employed for the composite assembly. The fruits were collected in the municipality of Governador Dix-Sept Rosado, Rio Grande do Norte State ( $5^{\circ} 28^{\prime} \mathrm{S}$ and $\left.37^{\circ} 31^{\prime} \mathrm{W}\right)$, Brazil. For the production of the composite, the fruits' seeds removed and then were washed in running water to remove the mucilage. The material was oven-dried at $80 \pm 2{ }^{\circ} \mathrm{C}$ for 24 hours, cut into rectangles and pre-pressed at $0.10 \mathrm{MPa}$ to obtain the flat mats depicted in Figure 1B.

The mats were placed in a mold together with crystal orthophtalic polyester resin. After assembling the matrix reinforcement, the mold was taken to a hydraulic press to start curing. Thereafter, pressed for 14 hours at $0.15 \mathrm{MPa}$. Specimens of dimensions $25 \mathrm{~mm}$ width x $2.7 \mathrm{~mm}$ thick $\mathrm{x} 25$ mm length were oven-dried at $100 \pm 2{ }^{\circ} \mathrm{C}$ for about 1 hour and used to determine the density of the manufactured composite using ASTM D792 (2008) standard.

The procedures described in the standard ASTM D3039 (2014) were followed for the tensile assays with 5 test specimens having dimensions of $25 \mathrm{~mm}$ width x $2.7 \mathrm{~mm}$ thickness x $240 \mathrm{~mm}$ length (Figure 2A).

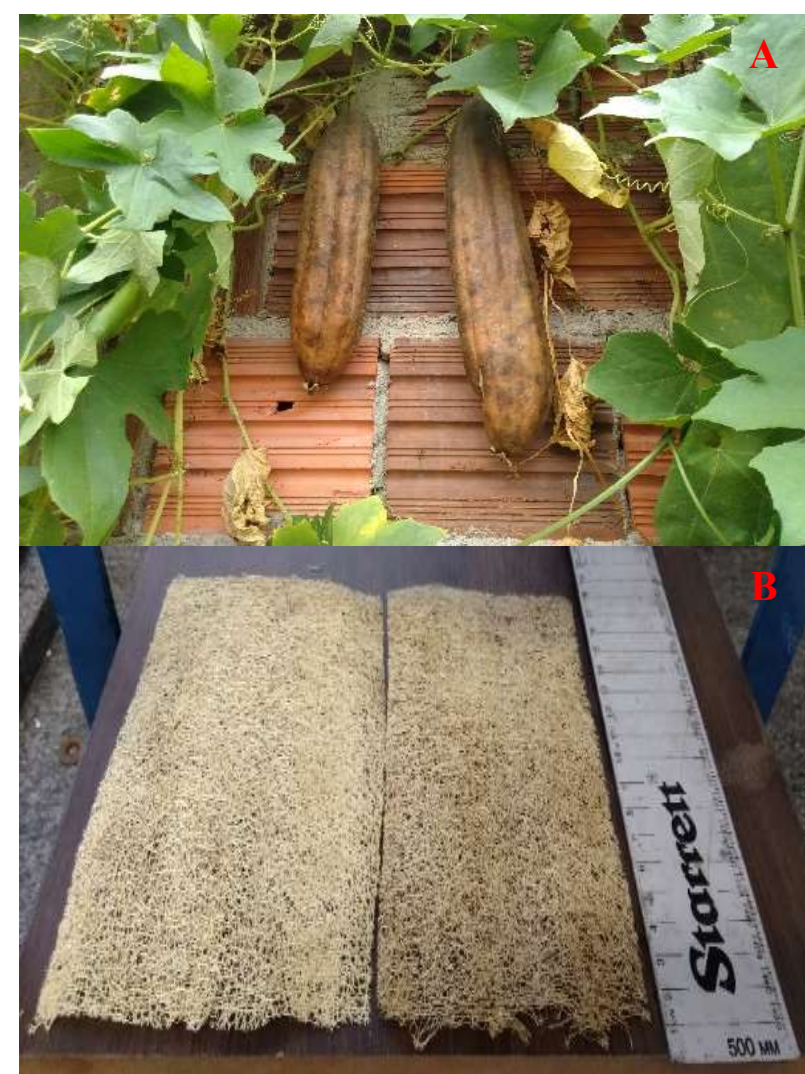

Figure 1. Fruits of Luffa cylindrica (A); Mats produced after cleaning (seed and debris removal) and pre-pressing (B).

Figura 1. Frutos de bucha - Luffa cylindrica (A); matéria-prima obtida após lavagem (remoção de sementes e sujeiras) e pré-pressagem (B).

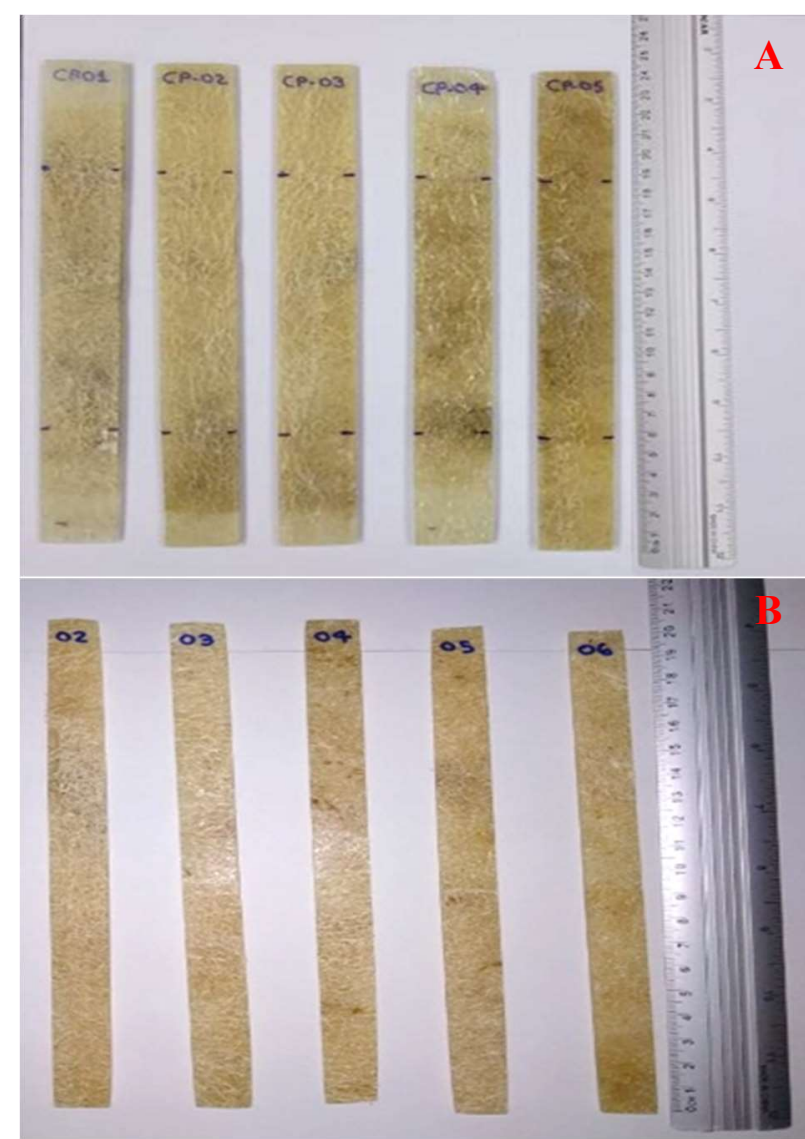

Figure 2. Test specimens for the tensile (A) and bending (B) assays. Figura 2. Corpos de prova utilizados para os ensaios de tração (A) e flexão estática (B). 
For the bending strength determination, the specimens were submitted to the procedures described in the standard ASTM D7264 (2015). These 5 test specimens had dimensions of $13 \mathrm{~mm}$ width $\times 3.6 \mathrm{~mm}$ thickness $\times 200 \mathrm{~mm}$ length (Figure 2B). The mechanical assays were performed employing an EMIC DL-10000 universal testing machine (São Paulo, Brazil) equipped with a $100 \mathrm{KN}$ load cell. Loading speeds of 1 and $2 \mathrm{~mm} \mathrm{~min}^{-1}$ were applied to the test specimens until complete fracture for the tensile and bending assays, respectively. With the values of rupture load from the machine and the dimensions of the test specimens, the maximum tensile load, deformation, and modulus of elasticity were obtained.

\section{RESULTS}

The composite produced with Luffa cylindrica fibers and polyester resin had mean density of $1.16 \pm 0.01 \mathrm{~g} \mathrm{~cm}^{-3}$ (Table $1)$.

Table 1. Density of the composite produced with Luffa cylindrica fibers and polyester resin.

Tabela 1. Densidade dos compósitos produzidos com fibras de bucha vegetal (Luffa cylindrica) e resina de poliéster.

\begin{tabular}{lc}
\hline Panels & Density $\left(\mathrm{g} \mathrm{cm}^{-3}\right)$ \\
\hline $\mathrm{CP}-01$ & 1.16 \\
$\mathrm{CP}-02$ & 1.15 \\
$\mathrm{CP}-03$ & 1.15 \\
$\mathrm{CP}-04$ & 1.16 \\
$\mathrm{CP}-05$ & 1.16 \\
\hline Mean & 1.16 \\
\hline Standard deviation & 0.01 \\
\hline
\end{tabular}

According to the tensile strength versus strain curves, the composite produced in this work did not reach the strength necessary for applications requiring high mechanical resistance (Figure 3).

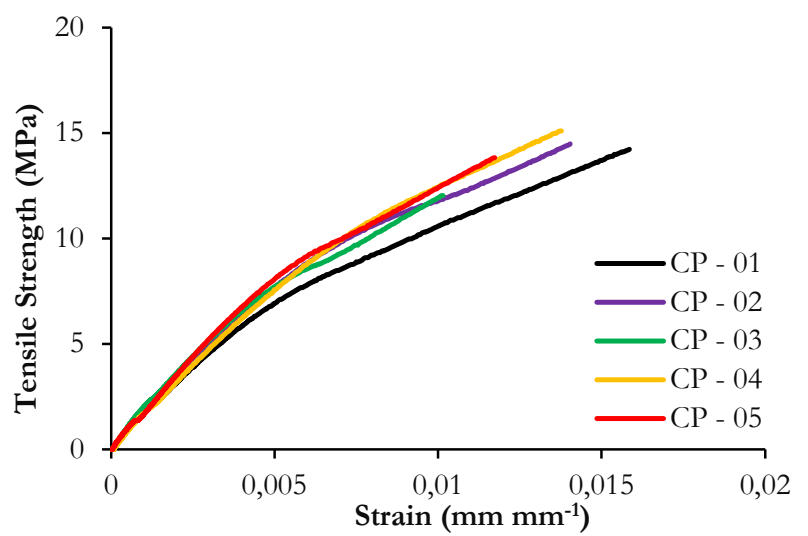

Figure 3. Curves obtained for the tensile strength $\mathrm{x}$ strain of the polyester-Luffa fiber composite.

Figura 3. Curvas observadas para os ensaios de tração dos compósitos confeccionados com fibra de bucha vegetal e resina de poliéster.

As displayed in Table 2, the tensile strength of the composite reached a maximum value of $13.91 \pm 0.77 \mathrm{MPa}$ with strain of $0.013 \pm 0.002 \mathrm{~mm} \mathrm{~mm}^{-1}$, and the modulus of elasticity was $1,076.57 \pm 93.70 \mathrm{MPa}$.

In the bending assays, the five composite test specimens presented higher resistance compared to the tensile stress. The behavior of this property indicated by the tension $\mathrm{x}$ strain curves is presented in Figure 4 while the values are in
Table 3. The results indicate that the composite evaluated in this work had better mechanical performance regarding bending rather than tensile stress.

The average values determined in the bending assays were $26.70 \pm 3.34 \mathrm{MPa}$ for strength, $0.035 \pm 0.0005 \mathrm{~mm} \mathrm{~mm}^{-1}$ for strain, and $772.99 \pm 106.38 \mathrm{MPa}$ for the modulus of elasticity. The composite reached bending strength and modulus of elasticity lower than the respective values of $102.02 \pm 20.88$ $\mathrm{MPa}$ and 5,092 $\pm 58.00 \mathrm{MPa}$ reported by Sapuan et al. (2020). Therefore, composites of polyester reinforced with Luffa cylindrica have mechanical properties suitable only for nonstructural applications, such as handicrafts and office partition.

Table 2. Values of tensile strength of the polyester-Luffa fiber composite.

Tabela 2. Valores observados para o ensaio de tração dos compósitos produzidos com bucha vegetal (Luffa cylindrica) e resina de poliéster.

\begin{tabular}{lccc}
\hline Panels & $\begin{array}{c}\text { Maximum strain } \\
\left(\mathrm{mm} \mathrm{mm}^{-1}\right)\end{array}$ & $\begin{array}{c}\text { Maximum } \\
\text { strain }(\mathrm{MPa})\end{array}$ & $\begin{array}{c}\text { Modulus of } \\
\text { elasticity }(\mathrm{MPa})\end{array}$ \\
\hline $\mathrm{CP}-01$ & 0.016 & 14.23 & 898.87 \\
$\mathrm{CP}-02$ & 0.014 & 14.34 & $1,020.02$ \\
$\mathrm{CP}-03$ & 0.010 & 12.04 & $1,186.28$ \\
$\mathrm{CP}-04$ & 0.014 & 15.10 & $1,096.99$ \\
$\mathrm{CP}-05$ & 0,012 & 13,85 & $1,180.67$ \\
\hline Mean & 0.013 & 13.91 & $1,076.57$ \\
S. deviation & 0.002 & 0.77 & 93.70 \\
\hline
\end{tabular}

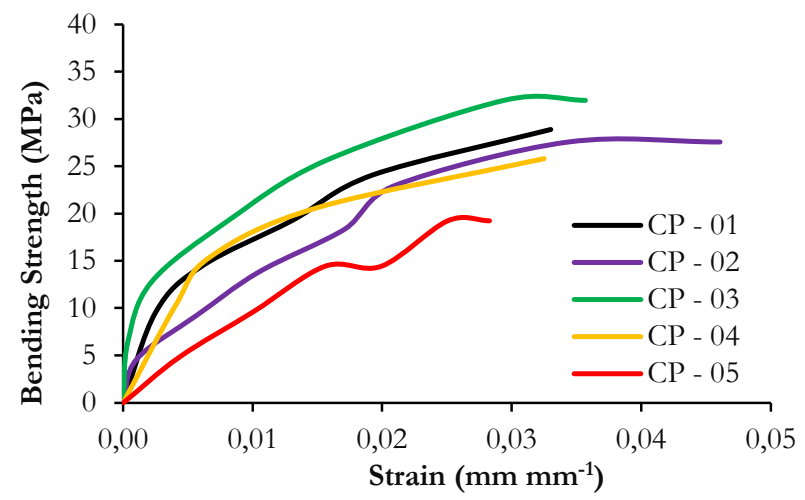

Figure 4. Curves obtained for the bending strength $\mathrm{x}$ strain of the polyester-Luffa fiber composite.

Figura 4. Curvas observadas nos ensaios de flexão estática para os compósitos produzidos com bucha vegetal (Luffa cylindrica) e resina de poliéster.

Table 3. Values determined in bending assays of the polyester-Luffa fiber composite.

Tabela 3. Valores observados para o ensaio de flexão estática dos compósitos produzidos com bucha vegetal (Luffa cylindrica) e resina de poliéster.

\begin{tabular}{lccc}
$\begin{array}{l}\text { Test } \\
\text { Specimen }\end{array}$ & $\begin{array}{c}\text { Maximum strain } \\
\left(\mathrm{mm} \mathrm{mm}^{-1}\right)\end{array}$ & $\begin{array}{c}\text { Maximum } \\
\text { strength }(\mathrm{MPa})\end{array}$ & $\begin{array}{c}\text { Modulus of } \\
\text { elasticity }(\mathrm{MPa})\end{array}$ \\
\hline $\mathrm{CP}-01$ & 0.033 & 28.91 & 876.35 \\
$\mathrm{CP}-02$ & 0.046 & 27.57 & 599.14 \\
$\mathrm{CP}-03$ & 0.036 & 31.99 & 896.22 \\
$\mathrm{CP}-04$ & 0.032 & 25.81 & 812.35 \\
$\mathrm{CP}-05$ & 0.028 & 19.26 & 680.88 \\
\hline Mean & 0.035 & 26.70 & 772.99 \\
S. deviation & 0.005 & 3.34 & 106.38 \\
\hline
\end{tabular}




\section{DISCUSSION}

The density results can be considered low compared to the original density of the polyester resin, of $1.21 \mathrm{~g} \mathrm{~cm}^{-3}$, as reported by Sapuan et al. (2020). Pérez et al. (2018), for a hybrid composite produced with polyester, fiberglass and cabuya fibers (Agave sp.), the final density was $1.46 \mathrm{~g} \mathrm{~cm}^{-3}$, and for one produced with polyester, fiberglass and abaca fibers (Musa textilis), the density reached $1.48 \mathrm{~g} \mathrm{~cm}^{-3}$. The final density determined in the present work for the composite reinforced with $L$ uffa fibers was lower than the values of 1.30 and $1.21 \mathrm{~g} \mathrm{~cm}^{-3}$ found by Ferreira et al. (2020) for composites produced with epoxy-fiberglass and epoxy-fiberglass-jute fibers (Corchorus capsularis).

Besides the low-density values found here, another positive characteristic of the composite is the biodegradability of the Luffa fibers. Furthermore, according to Dixit et al. (2017), the use of natural vegetable fibers gives composites other properties that are attractive for industrial purposes, in particular the low cost of these fibers compared to synthetic glass, aramid, carbon and steel fibers make them preferable in the composite industry (AHMAD et al., 2015).

The low tensile strength and the variations of the samples may have been related to impurities in the fibers causing poor interaction with the polyester matrix. Other factors responsible for this poor interaction could have been air bubbles and voids in the interface areas. In their research, Faria et al. (2020) show that the lay-up influences the mechanical properties of the composite, as it provides the appearance of a greater number of bubbles and voids. In thermoplastic composites reinforced with natural fibers, the strength and modulus of elasticity depend on the properties of the polymeric matrix and the impregnation in the interface region between matrix and fibers. In composites made with fragile matrices, the mechanical stresses exerted in the material may cause high tensions in the fibers, causing low resistance (WOIGK et al., 2019).

The composite does not have high tensile strength. However, the result found is superior to the value of $8.14 \pm$ $1.23 \mathrm{MPa}$ found by Sapuan et al. (2020). When compared to the polyester resin matrix, it was found that the addition of Luffa fiber reinforcement increased the material's tensile strength.

According to Patel et al. (2018), the increase in the percentage of natural fibers in a composite material caused an initial increase in the tensile resistance. However, after a critical point is reached, the bonding between the matrix and the fibers decreases, resulting in higher agglomeration and consequent loss of strength of the material.

Although the composite reached a better result in the bending assay, it presented variations in tension $\mathrm{x}$ strain curves and values similar to what was observed in the tensile assays. As occurred in the tensile assays, the variations might have been due to impurities in the material and the technique employed in the production of the composite. The chemical constituents of the natural fibers (cellulose, hemicellulose, lignin, waxes, pectin, etc.) could influence the mechanical properties of the composites including tensile, bending and impact resistance (LATIF et al., 2019).

As discussed by Latif et al. (2019), this influence arises from the presence of impurities and the chemical constituents those materials on the surface of the fibers, preventing good adherence between the reinforcement and the polymeric matrix. The interfacial and crystalline bonds are major factor affecting the mechanical properties of natural fibers. The mechanical properties are directly influenced by several factors, such as type of fiber, matrix, surface treatment and production method. Latif et al. (2019) further indicate that fibers without treatment tend to have non-cellulosic constituents and a smooth surface area, factors that cause lower mechanical interlock and incompatibility between the reinforcement of the fibers and the matrix material. SEM (Scanning Electron Micrographs) are highly recommended here for more detailed analysis of the results.

According to Elanchezhian et al. (2018), the employment of natural fibers in composites can give these materials low cost and mechanical properties desirable in civil construction and for the manufacture of partition panels, false ceilings, furniture, storage containers, tubes, bags, helmets and car and boat interior parts, among others.

\section{CONCLUSIONS}

The use of the Luffa fibers as reinforcement in the production of the composite provided low density and reduced the amount of resin used in the manufacturing process, making it economically feasible to use the material for various applications. In the tensile strength tests, the composite was fragile, indicating weak adhesion between the vegetable fibers and the polyester matrix.

Although the Luffa fibers did not provide the composite with a flexural strength higher than that of the polyester matrix, it still presented interesting results that allow the use of the material in the manufacture of products for nonstructural applications. In general, the addition of Luffa fibers resulted in good physical and mechanical properties for some uses.

\section{REFERENCES}

AHMAD, F.; CHOI, H. S.; PARK, M. K. A review: natural fiber composites selection in view of mechanical, light weight, and economic properties. Macromolecular materials and engineering, v. 300, n .1, p. 10-24, 2015. DOI: https://doi.org/10.1002/mame.201400089

AMERICAN SOCIETY FOR TESTING AND MATERIALS. ASTM D792-08: Standard test method for density and specific gravity (relative density) of plastics by displacement. ASTM: West Conshohocken, 2008.

AMERICAN SOCIETY FOR TESTING AND MATERIALS. ASTM D3039-14. Standard test method for tensile properties of polymer matrix composite materials. ASTM: West Conshohocken, 2014.

AMERICAN SOCIETY FOR TESTING AND MATERIALS. ASTM D7264-15: Standard test method for flexural properties of polymer matrix composite materials. ASTM: West Conshohocken, 2015.

BABU, V. R.; ARUMUGAN, A. The development of composites using Luffa fibre nonwoven for automotive application. International Journal of Mechanical and Production Engineering Research and Development, v. 8, n. 7, p. 1609-1616, 2019.

DIXIT, S.; DOEL, E.; DUBEY, A.; SHIVHARE, P. R.; BHALAVI, T. Natural fibre reinforced polymer composite materials - a review. Polymers from Renewable Resources, v. 8, n. 2, p. 71-78, 2017. DOI: $10.1177 / 204124791700800203$

ELANCHENZIAN, C.; RAMNATH, B. V.; RAMAKRISHNAN, G.; RAJENDRAKUMAR, M.; 
NAVEENKUMAR, V.; SARAVANAKUMAR, M. K. Review on mechanical properties of natural fiber composites. Materials Today: Proceedings, v. 5, n. 1, p. 1785-1790, 2018. DOI: 10.1016/j.matpr.2017.11.276

FARIA, D. L.; MESQUITA JÚNIOR, L.; MESQUITA, R. G. A.; GUIMARÃES JÚNIOR, M.; PIRES, N. J.; MENDES, L. M.; GUIMARÃES JÚNIOR, J. B. Production of castor oil-based polyurethane resin composites reinforced with coconut husk fibres. Journal of Polymer Research, v. 27, n. 249, 2020. DOI: https://doi.org/10.1007/s10965-020-02238-7

FERREIRA, C. R.; ARAÚJO, A. M.; FONSECA, J. C. M.; LEITE, R. F.; SILVA, I. A. P. Mechanical properties of sisal/ fiberglass reinforced composites. International Journal of Advanced Engineering Research and Science, v. 7, n. 3, p. 106-110, 2020. DOI: 10.22161/ijaers.73.17

LATIF, R.; WAKEEL, S.; KHAN, N. Z.; SIDDIQUEE, A. N.; VERMA, S. L.; KHAN, Z. A. Surface treatments of plant fibers and their effects on mechanical properties of fiber-reinforced composites: A review. Journal of Reinforced Plastics and Composites, v. 38, n. 1, p. 1530. 2019. DOI: $10.1177 / 0731684418802022$

MARTINEZ-PAVETTI, M. B.; MEDINA, L.; ESPÍNOLA, M.; MONTEIRO, M. Study on two eco-friendly surface treatments on Luffa cylindrica for development of reinforcement and processing materials. Journal of Materials Research and Technology, 2021. DOI: https://doi.org/10.1016/j.jmrt.2021.07.141

MEDEIROS, M. G. Caracterização e avaliação de acessos de bucha vegetal. 2015. 73f. Dissertação (Mestrado em Fitotecnia) - Universidade Federal Rural do Semi-Árido, Mossoró, 2015.

MOTA, M. K. F. Obtenção e caracterização de um compósito de matriz polimérica com carga de bucha vegetal (Luffa cylindrica). 2016. 104f. Tese (Doutorado em Engenharia Mecânica) - Universidade Federal do Rio Grande do Norte, Natal, 2016.

PATEL, V. K.; CHAUAN, S.; KATIYAR, J. K. Physicalmechanical and wear properties of novel sustainable Sour-weed fiber reinforced polyester composites. Materials Research Express, v. 5, n. 4, p. 1-16, 2018. DOI: $10.1088 / 2053-1591 /$ aabdd4

PÉREZ, C. F.; PAREDES, J. G.; VALENCIA, R. X.; VACA, W. H.; VÁSQUEZ, E. P. Logistic regression model for the grooving process of hybrid polyester resin composite materials reinforced with natural fibers and fiberglass. Materials Science and Engineering, v. 446, n. 1 , p. $1-8,2018$. DOI: 10.1088/1757899X/446/1/012003

SANJAY, M. R.; ARPITHA, G. R.; YOGESHA, B. Study on mechanical properties of natural-glass fibre reinforced polymer hybrid composites: A review. Materials today: proceedings, v.2, n. 4-5, p. 2959-2967, 2015. DOI: https://doi.org/10.1016/j.matpr.2015.07.264

SAPUAN, S. M.; AULIA, H. S.; ILYAS, R. A.; ATIQAH, A.; DELE-AFOLABI, T. T.; NURAZZI, M. N.; SUPIAN, A. B. M.; ATIKAH, M. S. N. Mechanical properties of longitudinal basalt/woven-glass-fiber-reinforced unsaturated polyester-resin hybrid composites. Polymers, v. 12 , n. 10 , p. 1-14, 2020. DOI: $10.3390 /$ polym 12102211
SARIKAYA, E.; ÇALLIOĞLU, H.; DEMIREL, H. Production of epoxy composites reinforced by different natural fibers and their mechanical properties. Composites Part B: Engineering, v. 167, n. 15, p. 461466, 2019. DOI: 10.1016/j.compositesb.2019.03.020

SRINIVAS, K.; NAIDU, A. L.; BAHUBALENDRUNI, M. V. A. R. A review on chemical and mechanical properties of natural fiber reinforced polymer composites. International Journal of Performability Engineering, v. 13 , n. 2 , p. 189-200, 2017. DOI: 10.23940/ijpe.17.02.p8.189200

WAHIT, M. U.; AKOS, N. I.; LAFTAH, W. A. Influence of natural fibers on the mechanical properties and biodegradation of poly (lactic acid) and poly ( $\varepsilon-$ caprolactone) composites: A review. Polymer Composites, v. 33, n. 7, p. 1045-1053, 2012. DOI: https://doi.org/10.1002/pc.22249

WOIGK, W.; FUENTES, C. A.; RION, J.; HEGEMANN, D.; VAN VUURE, A. W.; DRANSFELD, D.; MASANIA, K. Interface properties and their effect on the mechanical performance of flax fibre thermoplastic composites. Composites Part A: Applied Science and Manufacturing, v. 122 , n. 1, p. 8-17, 2019. DOI: 10.1016/j.compositesa.2019.04.015 